\title{
Glomus rubiforme, an arbuscular mycorrhizal fungus new to the mycota of Poland
}

\author{
JANUSZ BLASZKOWSKI, TADEUSZ MADEJ, and MARILSZ TADYCH
}

Depariment of Plant Pathology, Agricultural Academy in Szczecin

Slowackicgo 17, PL-71-434 Szczecin, Poland

Blaszkowski J., Madej T., $\mathrm{T}$ a d y ch M.: Glomus rubiforme, an arbaxtular mycorrhizal fimgus new to the mycota of Poland. Acta Mycol. 33 (2): 255-263, 1998.

Glomus rubiforme is described and illustrated, as well as its occurrence in Poland and in the world is presented. Glomus rubiforme forms pale yellow to light brown spores arranged in black berry-like sporocarps. The spores develop from a centrally positioned, inflated, thick-walled cell. The spore wall consists of two layers: a sloughing hyaline outer layer adherent to a coloured, laminated layer. Glomus rubiforme is a new arbuscular mycorrhizal fungus to the mycota of Poland.

Key words: hypogcous fungi, Glomus rubiforme, arbuscular mycorrhiza.

\section{INTRODUCTION}

Glomus rubiforme (Gerd. et Trappe) Almeida et Schenck has originally been described as Sclerocystis rubiformis Gerd. et Trappe (G e r d e m a n n and Trappe 1974). A $1 \mathrm{me} \mathrm{i} \mathrm{a} \mathrm{and} \mathrm{S} \mathrm{c} \mathrm{he} \mathrm{n} \mathrm{c} \mathrm{k} \mathrm{(1990)} \mathrm{transferred}$ all but one, $S$. coremioides Berk. et Broom, Sclerocystis species to the genus Giomus based on spore ontogeny. Spores of $S$. coremioides are formed individually on a subtending hypha that does not branch to form a new sporophore near the spore base, as was found in the other Sclerocystis species and some sporocarpic species of the genus Glomus. Although W u (1993) did not accept A l m e i d a and S c h c n c k's (1990) proposition, the current opinion of most taxonomists dealing with this group of fungi agree with the latter authors.

Reports of the occurrence of $G$. rubiforme are relatively not numerous (B hat ta charje et al. 1980; D a l pé 1989; D a l pé et al. 1986; Gerdemann and Trappe 1974; Grandi and Trufem 1991; 
G r a n d i et al. 1987; Ha 11 1977; H a mel et al. 1994; J o h n s o n 1977; M ille r et al. 1985; M os s and Bowe n 1968; M usoko et al. 1994; Nicols o n and $\mathrm{Schenck} \mathrm{1979;} \mathrm{Ragupathy}$ and Mahadevan 1993; S i everding 1989; Wu 1993; W u and $\mathrm{Ch}$ e $\mathrm{n} \mathrm{1986)}$ and this fungus has not so far been noted in Poland.

The aim of this paper is to describe and illustrate the specimens of G. rubiforme found in Poland. Additionally, this paper presents the distribution of this fungus in Poland and in the world.

\section{MATERIALS AND METHODS}

Collection of soil and root samples, as well as establishment of trap and single-species pot cultures were made as previously described (B I a s z k ow s k i 1997). The host plants used were Plantago lanceolata L., Sorghum sudanense (Staph.) Piper, and S. vulgare Pers. Plants were grown in a greenhouse at $18-30^{\circ} \mathrm{C}$ with supplemental $16-\mathrm{h}$ lighting provided by one SON-T AGRO sodic lamp (Philips Lighting Poland S. A.) placed $1 \mathrm{~m}$ above pots. The maximum light intensity was $180 \mu \mathrm{E} \mathrm{m}^{-2} \mathrm{~s}^{-1}$ at pot level. Plants were watered $2-3$ times a week. Trap cultures were harvested at ca 1 -month intervals, beginning 5 months and ending 12 months after plant emergence, spores extracted by wet sieving and decanting ( $G$ e r$\mathrm{dem}$ a n $\mathrm{n}$ and $\mathrm{Nicolson} 1963)$, roots stained in $0.05 \%$ trypan blue ( $\mathrm{Phillips}$ and $\mathrm{H}$ a y man 1970), and examined for the presence of mycorrhizae.

Because single-species cultures failed, morphological investigations of $G$. rubiforme were conducted based on field-collected specimens and those coming from trap cultures. At least 100 sporocarps mounted in polyvinyl alcohol/lactic acid/glycerol (PVLG; Kosk e and Tessier 1983) and 20 sporocarps mounted in PVLG mixed with Melzer's reagent $(1: 1, v / v)$ were examined. Wall characteristics of spores and terminology are those suggested by Fra n ke and M or to n (1994), S p a in et al. (1989) and W a $1 \mathrm{k}$ e $\mathrm{r}$ (1983). Spore colour was examined under a dissecting microscope on fresh specimens immersed in water. Colour names are from $\mathrm{K}$ o r n e r u p and W a n s c he r (1983). Specimens have been mounted on slides in PVLG and deposited in the Department of Plant Pathology (DPP), Academy of Agriculture, Szczecin, Poland. Nomenclature of other fungi follows W a Ik e r and Trappe (1993). Nomenclature of plants with which G. rubiforme was associated in Poland is according to $\mathrm{M} \mathrm{ir} \mathrm{e} \mathrm{k} \mathrm{et} \mathrm{al.} \mathrm{(1995).}$ The classification is that of M o r t o n and B e n y (1990). Explanation of the abbreviation used: Bl. - J. Blaszkowski. 


\section{DESCRIPTION AND DISCUSSION}

\section{Glomus rubiforme (Gerd. et Trappe) Almeida et Schenck}

Spores occurring in sporocarps in the soil. Sporocarps pale yellow (3A3) to light brown (6D8), globose, 200-260 $\mu \mathrm{m}$ diam. or ovoid, $100-200 \times 190-360 \mu \mathrm{m}$, without a peridium; with 3 to 18 spores (Fig. 1). Spores pale yellow (3A3) to light brown (6D8); globose to subglobose; $(40.0-) 52.0(-70.0) \mu \mathrm{m}$ diam. or oyoid to prolate; $35-45 \times 50-70 \mu \mathrm{m}$; with a single subtending hypha; developed from a thick-walled, inflated hypha; spores arranged in a hemispherical layer in young sporocarps or radially to form a blackberry-like sporocarp when mature (Fig. 1, 2, 3 and 4). Spore wall structure composed of one wall comprising two layers (layers 1 and 2, Fig. 3 and 4). Layer 1 , forming the spore surface, sloughing, smooth, hyaline, $(0.3-)$ $0.5(-0.8) \mu \mathrm{m}$ thick before disintegration, closely adherent to layer 2 . Layer 2 laminated (Fig. 2, 3 and 4), pale yellow (3A3) to light brown (6D8), (2.7-) $3.1(-3.7) \mu \mathrm{m}$ thick. Subtending hypha pale yellow (3A3) to light brown (6D)), straight to recurvate; funnel-shaped, sometimes cylindrical or constricted; (8.8-) $10.7(-14.2) \mu \mathrm{m}$ wide at the spore base (Fig. 1, 2, 3 and 4). Wall of subtending hypha pale yellow (3A3) to light brown (6D8), (2.9-) $4.8(-6.6) \mu \mathrm{m}$ thick, continuous with spore wall layers 1 and 2 (Fig. 3). Pore (1.5-) 2.2 $(-2.9) \mu \mathrm{m}$ wide, occluded by a septum, ca $2.0 \mu \mathrm{m}$ wide, continuous with the innermost lamina of wall layer 2, and occasionally by thickening of spore wall layer 2. Spore contents of oil droplets.

Polish colle ction ex a $\mathrm{m}$ in ed. Pobrzeże Kaszubskie-Żelistrzewo, under Pinus sylvestris + an unrecognized grass, 11.1985, Bł. 1029 (DPP); Jastrzébia Góra, under $P$. sylvestris + an unrecognized, 11.1985, Bł. 1030-1032; Jastrzębia Góra, under Lolium multiflorum, 11.1986, Bt. Mierzeja Helska-Hel, under Chamaecyparis lawsoniana, 7.1989, B1. Garb Tarnogórski-Pustynia Błędowska, under Potentilla sp., 7.1995, Bł. 1033-1036; Pustynia Blędowska, under Verbascum phlomoides, 7.1995, B1.; Boleslaw, under vascular plant, 9.1989, Bł. Wybrzeże Słowińskie-Słowiński National Park, under Ammophila arenaria, 6.1994, Bł. Równina Pyrzycka-Lipnik, under Triticum aestivum, 7.1992, BH.; Przelewice, under Agropyron repens + Picea abies, 5.1985, B1. Uznam and Wolin-Swinoujście, under Petasites spurius, 10.1992, Bt. Równina Wkrzańska - Police, under Calamagrostis arundinacea, 7.1992, B1.

D istribution and habitat. Of the over 1300 soil samples so far collected in ca 160 localities of Poland, G. rubiforme was found in 13 soils coming from 7 physiographic regions (Fig. 5). The soils represented both cultivated and uncultivated sites, the letter including forests, heaps, maritime and inland dunes. The spore abundance of $G$. rubiforme in $100 \mathrm{~g}$ dry soil ranged from 1 to 160 (av. 57.9). The proportion of spores of this fungus in spore 


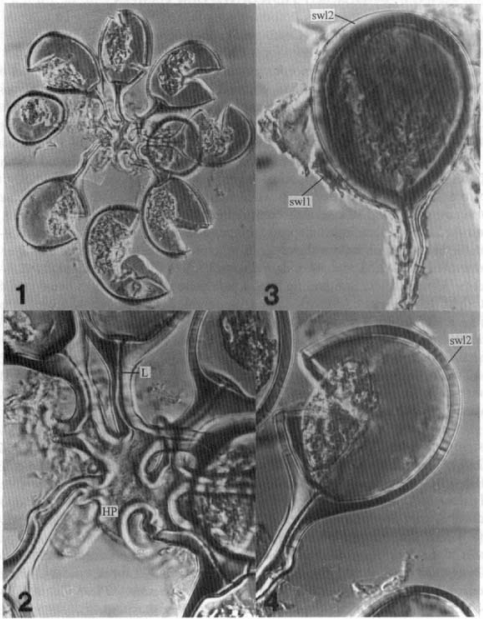

Fig. 1. Sporocarp with radially arranged spores, differential interference contrast (DIC), $\times 423$. Fig. 2. Thick-walled hyphal plexus (HP). Highly thickened walls and narrow lumens (L) of subtending hyphae are seen, DIC, $\times 2083$. Fig. 3. Spore wall layers 1 and 2 (swl 1, swl 2). DIC, $\times 1154$. Fig. 4. Mature spore with laminated sporc wall layer 2 (sw12) only. DIC, $\times 1154$ 


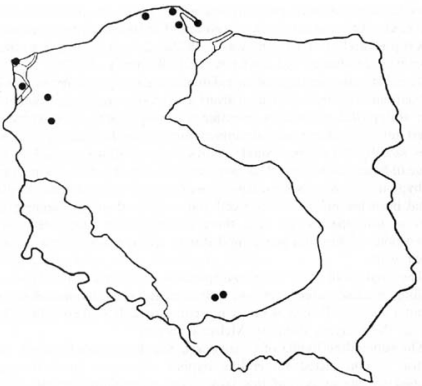

Fig. 5. Distribution of Glomus rubiforme in Poland

populations of all arbuscular mycorrhizal fungi recovered ranged from $1.56 \%$ to $86.41 \%$ (av. $37.51 \%$ ). The species riches of these fungi in soils in which G. rubiforme occurred ranged from 1 to 9 (av. 3.53). The plant species harbouring $G$. rubiforme were $A$. arenaria, $A$. repens growing near $P$. sylvestris, C. arundinacea, Ch. lawsoniana, L. multiflorum, Potentilla sp., V. phlomoides, $T$. aestivum, and unrecognized grasses. The fungi accompanying G. rubiforme were Acaulospora lacunosa Morton, A. mellea Spain et Schenck, A. paulinae Blaszk., Complexipes moniliformis Walker emend. Yang et Korf, Endogone flammicorona Trappe et Gerd, an undescribed Entrophospora sp., Gigaspora gigantea (Nicol. et Gerd.) Gerd. et Trappe, G. aggregatum Schenck et Smith emend. Koske, G. caledonium (Nicol. et Gerd.) Trappe et Gerd., G. constrictum Trappe, G. corymbiforme Blaszk., G. deserticola Trappe et al., G. etunicatum Becker et Gerd., G. fasciculatum (Thaxter) Gerd. et Trappe emend. Walker et Koske, G. ? geosporum (Nicol. et Gerd.) Walker, G. laccatum Blaszk., G. macrocarpum Tul. et Tul., G. microcarpum Tul. et Tul., G. mosseae (Nicol. et Gerd.) Gerd. et Trappe, unrecognized Glomus spp., Scutellospora armeniaca Blaszk. and $S$. dipurpurescens Morton et Koske. Except for $C$. moniliformis 
known to form ectendo- and ectomycorrhizac with coniferous trees ( $\mathrm{W}$ i lc o $x$ et al. 1983) and E. flammicorona found to be an ectomycorrhizal fungus ( $\mathrm{r}$ a p pe and $\mathrm{G}$ e r d e m a $\mathrm{n}$ 1972), the other fungi are arbuscular mycorrhizal producers (M orton and B e n y 1990).

The distinctive features of $G$. rubiforme are its sporocarps with relatively small, coloured spores originated from a centrally positioned hyphal plexus. When young, the sporocarps resemble a hemispherical layer. At times, they convert into blackberry-like structures due to the formation of subsequent spores radially developing. Single sporocarps sometimes are connected with hyphae in larger aggregates. The sporocarps are never enveloped in a peridium. The hyphal plexus of sporocarps consists of an inflated, thick-walled cell. Hyphal branches erect from this cell and swell at their tip, forming, thereby, spores of this species. At first, these branches are thin-walled. At times, they become thicker and more rigid due to the synthesis of further material in their wall.

The single wall of G. rubiforme spores is composed of two layers: a thin, sloughing, hyaline outer layer and a thicker, coloured, laminated inner layer. The outer spore wall layer is rarely present, especially in field-collected spores. None of these layers stains in Melzer's reagent.

The subtending hypha of $G$. rubiforme usually is funnel-shaped, although cylindric or constricted subtending hyphae were also found in specimens examined by the author of this paper. The subtending hyphal wall highly thickens with spore age due to the addition of material, mainly towards its lumen. This causes mature spores to usually have a subtending hypha with a narrow lumen connecting the spore inside with the hypha. The lumen in most mature spores is occluded by $1-3$ thick septa. Young sporocarps usually contain spores with subtending hyphae without septa.

Species of arbuscular fungi most similar in appearance to $G$, rubiforme are $G$. ambisporum Smith et Schenck, $G$. heterosporum Smith et Schenck, and $G$. taiwanense ( $\mathrm{Wu}$ et Chen) Almeida et Schenck. All the fungi produce spores in globular sporocarps. However, spores of $G$. ambisporum compared with those of $G$. rubiforme are larger $[85-157 \mu \mathrm{m}$ diam. vs. $27-125 \times 29-87 \quad(-110) \mu \mathrm{m} \quad($ A I m e id a and Schenck 1990); $27.5-60.0 \times 37.5-87.5 \mu \mathrm{m}$ (W u 1993); $(40.0-) 52.0(-70.0) \mu \mathrm{m}$ (Blaszkowski pers. observ.)], have a thicker wall $[6-18 \mu \mathrm{m}$ vs. $3.0-7.6$, up to $13.5 \mu \mathrm{m}$ at spore base (A I m e i d a and S c he n c k 1990); 1.5-6.0 (-8.5 $\mu \mathrm{m}$ (W u 1993); (2.7-) $3.1(-3.7) \mu \mathrm{m}$ (Blaszkowski pers. observ.)] with a reticulate outermost layer (vs. the smooth layer in $G$. rubiforme). Glomus heterosporum also forms larger spores $(99-206 \times 61-201 \mu \mathrm{m})$ than $G$. rubiforme; they frequently possess many subtending hyphae (a single subtending hypha in $G$. rubiforme). Additionally, both $G$. ambisporum and $G$. heterosporum are dimorphic fungi, whereas $G$. rubiforme has one type of spores. 
Although spores of $G$. rubiforme are in the same size range as those of G. taiwanense, the plexal hypha of the former fungus is a broad, thick-walled cell around which spores are produced, and that of the latter species is formed by fusion of more than one monohyphal stalk (W u 1993).

Glomus rubiforme probably is a widely distributed fungus in the world. Its occurrence has been reported in Florida, Michigan, New York, Oregon and Washington of the USA (G e r d e m a n and Trap p 1974; $\mathrm{M}$ ille $\mathrm{r}$ et al. 1985; $\mathrm{N}$ i cols on and $\mathrm{Schen} \mathrm{ck} \mathrm{1979),} \mathrm{in} \mathrm{Canada}$ (D a $1 \mathrm{p}$ é 1989; D a $1 \mathrm{pé}$ et al. 1986; $\mathrm{H}$ a m el et al. 1994), Brazil (Grandi and Trufem 1991; Grand i et al. 1987) and Colombia ( $\mathrm{S}$ i e verding 1989), England and Wales (M os e and B owen 1968), Cameroon (M u s o k o et al. 1994), India (B h a t t a c ha $\mathrm{j}$ e e et al. 1980; R a g u p thy and $\mathrm{M}$ a h a deva n 1993), Taiwan (W u 1993; W $\mathrm{u}$ and $\mathrm{Ch}$ en 1986) and New Zealand (H a 11 1977; J o h nson 1977; Mosse and B ow en 1968).

Acknowledgment: This study was supported in part by The Committec for Scientific Research. a grant no. 6.P04C.015.13.

\section{REFERENCES}

A $1 \mathrm{me}$ ida R. T, S che nck N. C. 1990. A revision of the genus Sclerocystis (Glomaceae, Glomales). Mycologia 82: 703-714.

Bhat acharjee M., Mukerji K. G., M is a S. 1980. Studies on Indian Endogonaceae. III. Further records. Acta Bot. Indica 8: 99-102.

B tas z k o skj J. 1997. Glomus gibbosum, a new species from Poland. Mycologia 89 $341-347$.

D a 1 pé Y. 1989. Inventaire et repartition de la flore endomycorhizienne de dunes et de rivages maritimes du Quebec, du Nouveau-Brunswick et de la Nouvelle-Ecosse. Naturaliste can. Rev. Ecol. Syst., 116: 219-236.

Dalpé $Y_{4}$ Granger R. L., Furlan V. 1986. Abondance relative et diversite des Endogonacees dans un sol de verger du Quebec. Canad. J. Bot. 64: 912-917.

F r a n k M, M orto n J. B. 1994. Ontogenetic comparisons of arbuscular mycorrhizal fungi Scutellospora heterogama and Scutellospora pellucidas revision of taxonomic character concepts, species descriptions, and phylogenetic hypotheses. Canad. J. Bot. 72: $122-134$.

Gerdemann J. W., Nicolson T. H. 1963. Spores of mycorrhizal Endogone species extracted from soil by wet sieving and decanting. Trans. Br. Mycol. Soc. 46: 235-244.

Gerdema n n J. W. T r a p p e J. M. 1974. The Endogonaceae in the Pacific Northwest. Myc. Memoir 5: 1-76.

Gra nd i R. A. P. Trufe m S. F. B. 1991. Fungos micorrizocos vesiculo-arbusculares $\mathrm{em}$ Marantaceae cultivadas no Instituto de Botânica, Säo Paulo, SP. Revta Brasil. Bot. 14: $89-95$.

Grandi R. A. P., Trufem S. F. B., Komesu S. T. 1987. Fungos micorrizocos em quatro espécies de Marantaceae. P. I. In: Reuniâo Brasileira sobre Micorrhizas, Säo Paulo, SP. 
$\mathrm{H}$ a 11 I. R. 1977. Species and mycorrhizal infections of New Zealand Endogonaceae. Trans. Br. Mycol. Soc. 68: $341-356$.

Hamel C, Dalpé Y, Lapierre C, Simard R. R, S mith D. L. 1994. Composition of the vesicular-arbuscular mycorrhizal fungi population in an old meadow as affected by $\mathrm{pH}$, phosphorus and soil disturbance. Agric. Ecosys. Environ. 49: 223-231.

J o h n s o n P. N. 1977. Mycorrhizal Endogonaceae in a New Zealand forest. New Phytol. 78: $161-170$.

K o n d ra c k i J. 1998. Geografia regionalna Polski. PWN, Warszawa.

K o r n e r up A., W a ns che r J. H. 1983. Methuen handbook of colour. $3^{\text {rd }}$ ed. E. Methuen and $\mathrm{Co}_{2}$, Ltd., London.

K o s k c R. E., Tess i c r B. 1983. A convenient, permanent slide mounting medium. Newsl. Mycol. Soc. Am. 34:59.

Mille r D. D., Dom o to P. A., W a $1 \mathrm{k}$ e r C. 1986. Mycorrhizal fungi at eighteen apple rootstock plantings in the United States. New Phytol. 100: 379-391.

M irek Z. Pickos-M irkow a. H. Z a j a c A, Z a ja c M. 1995. Vascular plants of Poland. A Checklist. Polish Botanical Studies, Guidebook 15, Kraków, 303 pp.

M ort o n J. B., B e n n y G. E. 1990. Revised classification of arbuscular mycorrhizal fungi (Zygonycetes): a new order, Glomales, two new suborders, Glomineae and Gigasporineae, and two new families, Acaulosporaceae and Gigasporaceae, with an emendation of Glonaceac. Mycotaxon 37: $471-491$.

M os s e B., B o w e n G. D. 1968. The distribution of Endogone spores in some Australian and New Zealand soils, and in an experimental field soil at Rothamsted. Trans. Br. Mycol. Soc. 51: $485-492$.

M us ok o M., Last F. T., M a s on P. A. 1994. Populations of spores of vesicular-arbuscular mycorrhizal fungi in undisturbed soils of secondary semideciduous moist tropical forest in Cameroon. Forest Ecol. Management 63: 339-377.

$\mathrm{N}$ i c ols o n T. H., S che n ck N. C. 1979. Endogonaceous mycorrhizal endophytes in Florida. Mycologia 71: 178-198.

P hill i ps J. M., H a y m a n D.S. 1970. Improved procedures for clearing roots and staining parasitic and vesicular-arbuscular mycorrhizal fungi for rapid assessment of infection. Trans. Br. Mycol. Soc. 55: 158-161.

Ragupath y S., $\mathrm{M}$ a ha d e va n A. 1993. Distribution of vesicular-arbuscular mycorrhizac in the plants and rhizosphere soils of the tropical plains, Tamil Nadu, India. Mycorrhiza 3: 123-136.

$\mathrm{S}$ ie v o r d in g E. 1989. Ecology of VAM fungi in tropical agrosystems. Agric. Ecosys. Environ. 29: $369-390$.

S p a in J. L., S i e v e r d i n g E., S e h e n c k N. C. 1989. Gigaspora ramisporophora: a new species with novel sporophores from Brazil. Mycotaxon 34: 667-677.

T r a p pe J. M., G e r d e m a n n J. W. 1972. Endogone flammicorona sp. nov, a distinctive segregate from Endogone lactiflua. Trans. Br. Mycol. Soc. 59: 403-407.

W a $1 \mathrm{ke} \mathrm{r} \mathrm{C.} \mathrm{1983.} \mathrm{Taxonomic} \mathrm{concepts} \mathrm{in} \mathrm{the} \mathrm{Endogonaceae:} \mathrm{Spore} \mathrm{wall} \mathrm{characteristics} \mathrm{in}$ species descriptions. Mycotaxon 18: 443-455.

W a $1 \mathrm{ke}$ r C., T t a p pe J. M. 1993. Names and epithets in the Glomales and Endogonales. Mycol. Res. 97: $339-344$.

Wilcox H. E, Y ang C. S., Lo Buglio K. 1983. Responses of pine to E-strain cctendomycorrhizal fungi. Plant and Soil $71: 239-247$.

W u C.G. 1993. Glomales of Taiwan: IV. A monograph of Sclerocystis (Glomaceae). Mycotaxon 49: $327-349$.

W u C.-G., C he n Z. C. 1986. The Endogonaceae of Taiwan. I. A preliminary investigation on Endogonaceae of babmbo vegetation at Chi-Tou areas, Central Taiwan. Taiwania 31: $65-88$. 
Glomus rubiforme, arbuskularny grzyb mikoryzowy nowy dla Polski

Opisano i zilustrowano oraz przedstawiono wysteppowanie w Polsce i świecie Giomus nubiforme, arbuskularnego grzyba mikoryzowego, Glomus rubiforme tworzy jasnożolte lub jasnobrazowe zarodniki skupione $w$ sporokarpach przypominających owoce jeżyny. Zarodniki te tworzą sį z grubościennej, rozdẹtej komórki umiejscowionej w śodku sporokarpu. \$ciana zarodników sklada sį̨ $z$ dwóch warstw: złuszezającej się, hialinowej warstwy zewnẹtrznej przylegajacej do zabarwioncj warstwy daminowanej. Glomus rubiforne jest grzybem nowym dla mycota Polski. 